\title{
Effects of selective logging on large mammal populations in a remote indigenous territory in the northern Peruvian Amazon
}

\author{
$\underline{\text { Pedro Mavor }}^{1,2}, \underline{\text { Pedro Pérez-Peña }}^{3}, \underline{\text { Mark Bowler }}^{4}, \underline{\text { Pablo E. Puertas }}^{2,5}$, Maire Kirkland $^{2}$ and Richard Bodmer $^{2,6}$
}

\begin{abstract}
We examined the effects of selective timber logging carried out by local indigenous people in remote areas within indigenous territories on the mammal populations of the Yavari-Mirin River basin on the Peru-Brazil border. Recent findings show that habitat change in the study area is minimal, and any effect of logging activities on large mammal populations is highly likely to be the result of hunting associated with logging operations. We used hunting registers to estimate the monthly and yearly biomass extracted during timber operations and to calculate the catch per unit effort (CPUE) in subsistence hunting in the community of Esperanza 2 to 5 years before logging activities started and 4 to 7 years after logging began. We also used line transects and the distance method to estimate animal densities before and after logging. We found that 1389 hunted animals and 27,459 $\mathrm{kg}$ of mammal biomass were extracted per year from logging concessions. CPUE for ungulates declined; however, it increased for other mammal orders, such as rodents and primates, indicating a shift to alternative prey items. Although collared peccaries (Pecari tajacu) and tapirs (Tapirus terrestris) may also have declined in numbers, this shift may have been caused by a possibly natural population crash in white-lipped peccaries (Tayassu pecari) that coincided with the logging periods. We found no evidence that populations of primates were reduced by the logging activities. Because primates are sensitive to hunting, and their populations were of principal concern as logging commenced, this indicates that these forests remain of high conservation value. The unusual socioeconomic situation of these remote territories may mean that they are compatible with wildlife conservation in the Yavari-Mirin basin.
\end{abstract}

Key Words: Amazon; catch per unit effort; hunting; mammal density; timber logging

\section{INTRODUCTION}

Timber extraction is widespread in humid tropical forests. In Peru, timber concessions are granted by the government to facilitate the selective extraction of the most commercial species. Legal extraction from these concessions requires plans for reforestation, minimizing the socio-cultural effect on the local people and the biological effect on the environment (MINAG 2009). Although many studies have explored the social, economic, and ecological effects of timber concessions (Uhl et al. 1991, Verissimo et al. 1992, Watson 1996, Lescuyer et al. 2012), most have focused on the effects on lumber species targeted for extraction, and relatively few on game and other wildlife species (Rist et al. 2011). However, it has been repeatedly shown that timber operations cause widespread negative effects on wildlife populations, including population declines and local extinctions, as well as other effects such as infant malnutrition, abandonment, and mortality (Thiollay 1992, Marsden 1998, Meijaard et al. 2006). This is thought to be, in part, an indirect result of deforestation and habitat destruction. Deforestation and disturbance may also result in forest fragmentation, with subsequent wildlife isolation by reducing the available habitat and limiting connectivity, causing a reduction in suitable habitat for certain species as a result of the "edge effect" (Laurance et al. 2000, Broadbent et al. 2008). Nevertheless, to our knowledge there is no information on the ecological effect of logging activities carried out by local indigenous people in remote areas within the framework of timber concessions or within indigenous territories.

In the Amazon, logging operations on timber concessions, indigenous territories, and surrounding areas are often associated with an increase in hunting pressure (Robinson et al. 1999). Timber companies rely on bushmeat hunting for subsistence and financial income, and employees of these companies are encouraged to hunt to offset the debt incurred by the companies until they are able to sell the lumber (Bodmer et al. 1988, Robinson et al. 1999). Because financial gain is an important driving force for timber companies, lumbermen often hunt the large primates for subsistence and sell the more economically valuable bushmeat of lowland tapir (Tapirus terrestris), brocket deer (Mazama spp.), and peccary (Pecari tajacu and Tayassu pecari) to urban markets. Thus, hunting promoted by timber operations may cause rapid declines in primate and tapir populations because these are mammals with slow reproductive rates (Pukazhenthi et al. 2013, Bowler et al. 2014).

We examined the effects of selective timber logging on the mammal populations of the Yavari-Mirin basin, a remote area on the Peru-Brazil border. The Yavari basin harbors a high diversity of mammals. Of up to 150 mammal species, 14 are primates (Salovaara et al. 2003), and 27 are threatened species (Bodmer et al. 2003). This biodiverse region has been compromised by several economic booms and busts produced by more than a century of resource extraction, including rubber, timber for fine-grade furniture, rosewood oil for perfume, and jaguar (Panthera onca), otter (Pteronura brasiliensis), and peccary (Bodmer and Puertas 2003) pelts. Following the 1970s, the human population began to decline in the Yavari because the resources were exhausted and a deadly outbreak of endemic, chloroquineresistant malaria hit the region in 1995 (Bodmer and Puertas 2003).

The Yavari-Mirin basin, feeding the middle section of the Yavari River, is an extremely diverse landscape, ranging from upland forests with nutrient-poor sandy soils to flooded forests with 
Fig. 1. Map of the study area, including the sampling sites before and after logging operations, the Yavari and Yavari-Mirin Rivers, the local community of Nueva Esperanza, the Lago Preto Paredon Conservation Concession, the Tamshiyacu-Tahuayo Regional Conservation Area, and the forestry concessions.

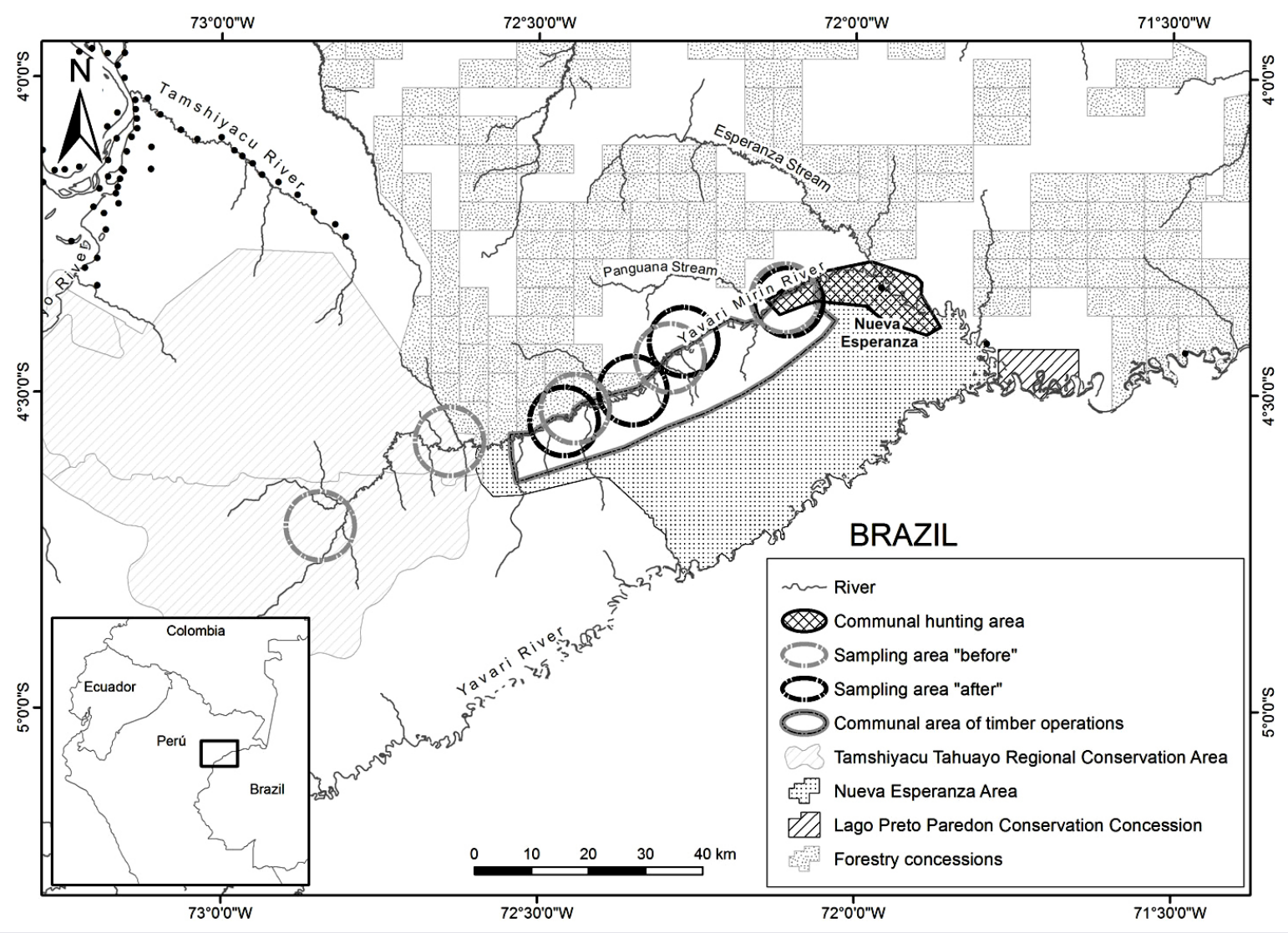

relatively nutrient-rich soils (Pitman et al. 2003). The only village still occupied in the Yavari-Mirin is Nueva Esperanza (04 $19^{\prime} 53^{\prime \prime}$ S, 71 ${ }^{\circ} 57^{\prime} 33^{\prime \prime} \mathrm{W}$; Fig. 1), with a population of 281 persons. The main human activities are traditional small-scale agriculture, though domestic animals are scarce; fishing; logging; and subsistence hunting.

In 2004, the Peruvian government issued timber concessions that covered large areas of the Yavari-Mirin basin. Timber extraction in forest concessions was carried out on a medium scale and with minimal mechanization. Lumbermen used chain saws and axes to harvest timber and shotguns and machetes to hunt, and, rather than cutting long roads through the forest, they cut short paths to reach small uplands streams, which they then used to float the timber downstream. Parallel to the timber concessions, concessionaries promoted logging activities by local indigenous people within communal territories. Logging in this region was selective, with only the most economically valuable species extracted, because of the area's isolation from the urban markets of Iquitos and Leticia (Fig. 2). Initially, after the establishment of timber concessions, the most targeted species was the highly commercial species Cedrela odorata, but in the following years, timber operations focused on the lower value commercial species (Fig. 2). Analysis of Landsat satellite images from the years 2000 , 2005 , and 2010 of the areas logged by indigenous people in the
Fig. 2. Total timber extraction and extraction per species between 2005 and 2014 in the Yavari basin (Regional Program of Forestry and Wildlife Management of Loreto-Perú, personal communication).
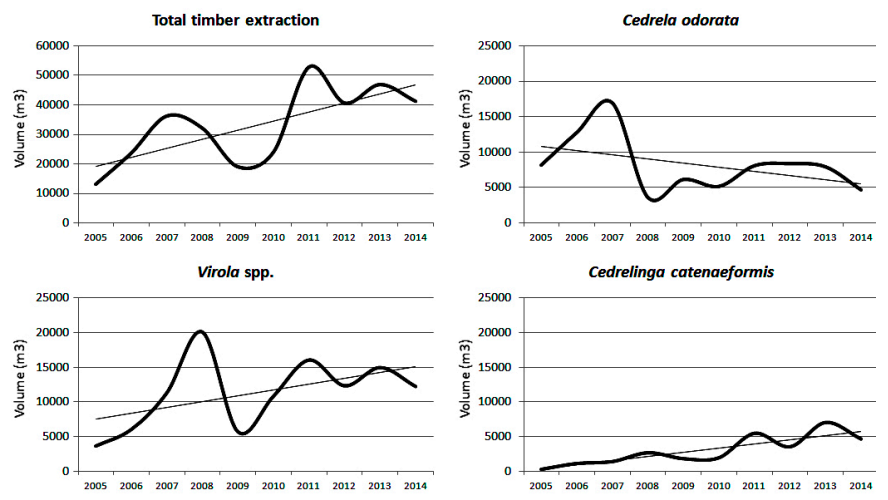

Cedrelinga catenaeformis
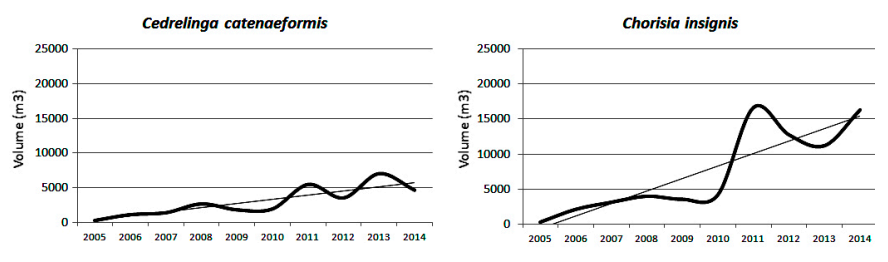
Yavari-Mirin basin (Mercado 2012) showed that forest cover in the 192,266-ha area ranged from $99.0 \%$ to $99.4 \%$, and disturbed areas from $0.6 \%$ in 2000 to $0.8 \%$ in 2010 . During the $2000-2005$ period, the rate of loss of forest cover was $201 \mathrm{ha} /$ year (deforestation rate of $0.10 \%$ ), and for the period 2005-2010, it was $117 \mathrm{ha} /$ year (deforestation rate of $0.60 \%$ ). In 2010, the total disturbed area was $0.8 \%$ of the entire area. Most of this very minor change in forest cover was because of logging camps and associated agriculture and is indicative of a very selective logging regime focused on high-value species and leaving a relatively intact forest canopy and no signs of fragmentation.

Selectively logged forests are often considered "degraded," and in Peru and other Amazonian countries, they are often converted to other land uses, such as plantations, agriculture, or urban areas (Xingli et al. 2011). However, the scientific community is now reconsidering the environmental value of modified habitats, including secondary forests and selectively logged forests (Sheil and Meijaard 2010, Miller et al. 2011, Putz et al. 2012). A growing body of evidence that these habitats can be valuable for biodiversity conservation has spurred a paradigm shift toward protecting these so-called degraded habitats (Sodhi et al. 2005, Barlow et al. 2007, Edwards et al. 2011, Gibson et al. 2011, Slade et al. 2011). We compare hunting and large mammal populations in the forests of the Yavari-Mirin basin before and after timber operations began to understand the effects that selectively logged indigenous territories in remote areas have on large mammals.

\section{METHODS}

\section{Hunting registers}

Local villagers registered all prey hunted during both subsistence and logging activities, in 2 separated areas within their own territory (Fig. 1). The community's subsistence hunting activities were concentrated in an area of $422 \mathrm{~km}^{2}$, which included forest patches, secondary forest, and house gardens or fields, and hunting during logging activities was concentrated within 1500 $\mathrm{km}^{2}$ of continuous forest (Fang et al. 2008). Whereas subsistence hunting in the communal hunting area occurs year-round, loggerhunters hunt for only 4 months during the rainy season because logs are extracted via streams when water levels are high. We recorded the extraction of bushmeat in logged areas to measure the extent of the hunting pressure and used before and after measures of catch per unit effort (CPUE) in community hunting areas to measure changes in game abundance.

\section{Bushmeat extraction in logged areas}

Within the indigenous territory, 15 logging camps were identified, with $11.6 \pm 4.2$ persons per camp (including 2 hunters per camp), totaling 174 persons working in the whole area $\left(603 \mathrm{~km}^{2}\right)$. The season for Cedrela odorata lasts on average for 4 months per year. Harvest data from $5(33.3 \%)$ timber concessions were collected using registers from 10 local hunters between 2011 and 2014, 6 to 10 years after timber operations began. A total of 326 days of hunting registers were surveyed. There was no commercial timber activity before 2004. We estimated the monthly and yearly biomass extracted during timber operations and weight of bushmeat consumed by loggers, using the total number of individuals and weight of each extracted species (Peres and Dolman 2000, Bardales García et al. 2004).
Catch per unit area in communal hunting areas

Harvest data from normal subsistence hunting in the community of Esperanza were gathered using hunting registers with 41 participating hunters between 1999 and 2002, 2 to 5 years before timber operations began, recording 1699 collective hunting days, and again between 2008 and 2011, 4 to 7 years after timber operations began, with 8 hunters recording 546 collective hunting days. Hunting registers included the number, species, and sex of hunted animals, as well as day and site of hunting. For registers between 2008 and 2011, to ensure that days on which no kills were made were registered in the effort, we interviewed the 8 hunters keeping hunting registers to estimate their hunting frequency. The difference between this total number of hunting days and the number recorded hunting registers was used to estimate the frequency of unsuccessful hunts and to adjust the total number of hunting days. Between 1999 and 2002, the method differed slightly in that nonsuccessful hunting days were recorded directly in the registers. CPUE was calculated for each mammal species from data pooled from all sampled hunters using the following formula: CPUE = number of kills/100 hunting days.

\section{Density and abundance of mammal populations}

Large mammal populations were surveyed in the Yavari-Mirin River between 1992 and 1999 (survey 1), 5 to 12 years before the timber operations began, and again between 2011 and 2014 (survey 2), 7 to 10 years after timber operations began (Fig. 1). Before logging operations began, sites in the mid- and upper sections of the Yavari-Mirin were surveyed, but after logging operations began, logistics only permitted surveys in the midsection of the river. In each period, 20 trails of approximately $5 \mathrm{~km}$ were cut prior to the surveys, and each was walked multiple times. A total of $939 \mathrm{~km}$ and $1607 \mathrm{~km}$ of survey effort was accrued in surveys 1 and 2, respectively. The distance sampling method was used (Buckland et al. 1993), in which 1 or 2 observers walked transects between 0700 and 1500 hours. When a group of animals was encountered, the number of individuals was recorded, and the perpendicular distance from the trail to the first individual sighted was measured. The data were analyzed using Distance 4.0 and 6.0 software. Population densities were calculated (number of individuals $/ 100 \mathrm{~km}^{2}$ ), but for species with fewer than 8 observations, this was substituted with an abundance index (number of individuals $/ 100 \mathrm{~km}$ ).

\section{RESULTS}

\section{Hunting registers}

Bushmeat extraction in logged areas

Hunting in concession forests and logged indigenous territories is concentrated within the 4 months of active logging typically possible in a year. Between 2012 and 2014, 1389 hunted animals and $27,459 \mathrm{~kg}$ of mammal biomass were extracted per year. The daily rate of bushmeat consumption by workers was $1.44 \pm 0.45$ $\mathrm{kg}$ (corresponding to $502 \mathrm{~g}$ of meat) per person. Daily bushmeat consumption in the whole study area, 174 workers in 15 logging camps, was $246.1 \mathrm{~kg}$. Ungulates were the most hunted, making up $45.4 \%$ of individuals and $78.9 \%$ of biomass extracted (Table 1). However, the mammal most frequently hunted animal during logging activities in the Yavari-Mirin in terms of the number of individuals was a rodent, the paca (Cuniculus paca; Table 2). The species making up the greatest biomass of extracted animals was 
the collared peccary ( $P$. tajacu), very closely followed by the lowland tapir (T. terrestris). The tapir provides a large amount of meat, and although the number of individuals hunted was low relative to other species, an estimated 1 tapir was killed every 2 days in the 15 logging camps. The red brocket deer (Mazama americana) and the Poeppig's woolly monkey (Lagothrix poeppigii) were also frequently hunted. Most other species, including other primates, large rodents, edentates, marsupials, and carnivores, were rarely hunted during logging activities. Notably, the white-lipped peccary (T. pecari) did not appear in the hunting registers, following the unexplained and almost complete disappearance of the herds at an early stage of logging activity (Fang et al. 2008).

Table 1. Harvest rates of mammal groups by 15 camps during timber operations, shown in terms of individuals and biomass extracted.

\begin{tabular}{lcc}
\hline \hline Group & $\begin{array}{c}\text { Number of Individuals } \\
\text { Extracted } \\
\text { per Year }(\%)\end{array}$ & $\begin{array}{c}\text { Biomass in Kilograms } \\
\text { Extracted } \\
\text { per Year }(\%)\end{array}$ \\
\hline Ungulates & $630.9(45.4)$ & $21,657.8(78.9)$ \\
Rodents & $461.5(33.2)$ & $3530.5(12.9)$ \\
Primates & $227.1(16.3)$ & $1857.2(6.8)$ \\
Edentates & $64.7(4.7)$ & $388.1(1.4)$ \\
Carnivores & $5.1(0.4)$ & $25.7(0.1)$ \\
Total & $1389.3(100.0)$ & $27,459.3(100.0)$ \\
\hline
\end{tabular}

Catch per unit area in communal hunting areas

CPUE for all species combined declined in the communal hunting area of Esperanza from 131.6 individuals per 100 hunting days for the period 1990 to 1999 to 76.1 individuals per 100 hunting days for the period 2007 to 2011, indicating that more days hunting were required to kill similar numbers of animals. CPUE declined drastically for ungulates (Fig. 3A), largely accounted for by the almost complete disappearance of the white-lipped peccary, and CPUE also declined for the other ungulates (Fig. $3 \mathrm{~B})$, with kill rates for the tapir and the collared peccary between 2007 and 2011 , falling to $26 \%$ and $39 \%$, respectively, of what they were between 1990 and 1999. Conversely, the numbers of rodents and primates and other groups killed per days hunting increased, with kill rates of the large rodent paca increasing by 4.5 times between the 2 periods. For the already targeted woolly monkey, CPUE remained similar, but for other primates, including the vulnerable red uakari monkey (Cacajao calvus), CPUE increased.

\section{Comparison of mammal populations before and after timber operations began}

Although we cannot measure population change directly because of differences in sampling area, the densities calculated for the mid- and upper sections of the Yavari-Mirin before the logging operations (survey 1) provide a baseline for the area under conditions of very low hunting pressure with which we can usefully compare densities calculated for the midsection of the Yavari-Mirin after several years of logging activity (survey 2; Table 3). The large atelid primates (Lagothrix, Ateles, and Alouatta) were all found at higher densities in survey 2 than survey 1, whereas calculated densities for small- and medium-bodied primates were similar or lower. Thus, we found no evidence for lower than expected populations of the most hunted primates Lagothrix and Ateles in the midsection of the river in survey 2.
Fig. 3. Catch per unit effort (CPUE) of hunters from the village of Esperanza on the Yavari-Mirin River between 1990 and 1999 before logging operations (based on 41 hunters) and between 2007 and 2011 (based on 8 hunters, 16\%): (A) divided into animal orders and (B) divided into the main hunted species and the primates.
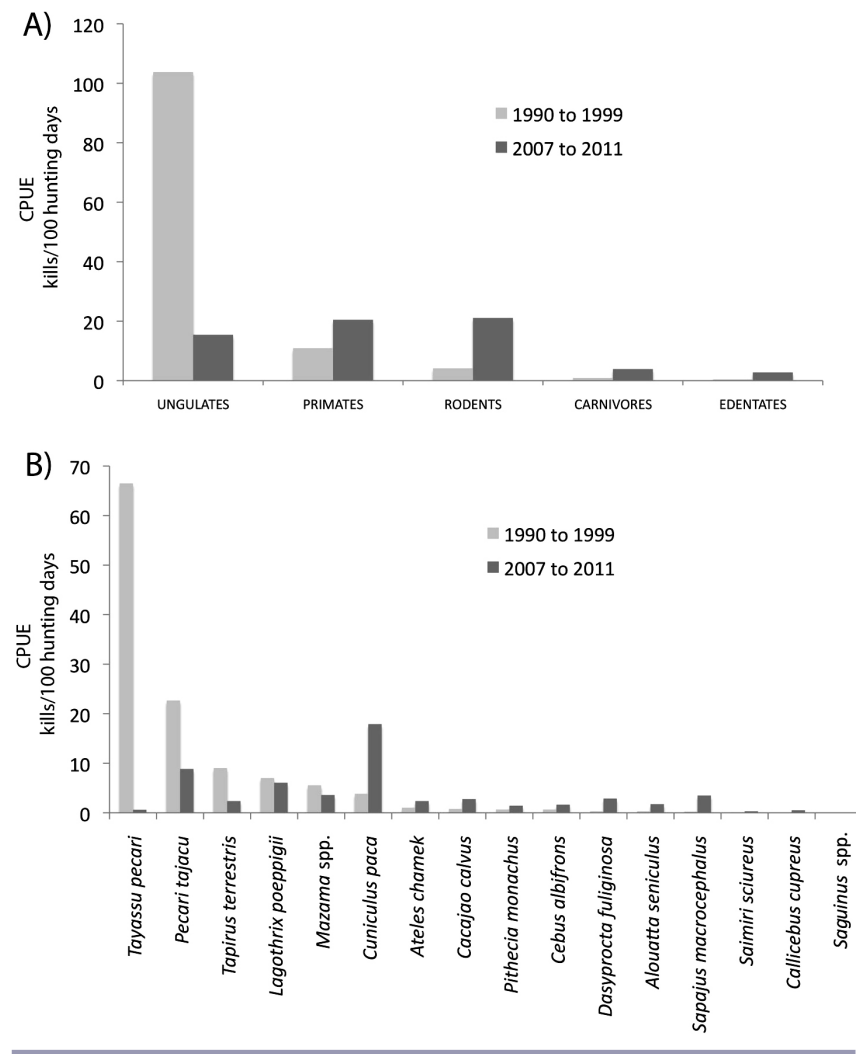

Densities of ungulates did differ between survey 1 and survey 2 . Although densities of brocket deer were very similar, the recorded densities of white-lipped peccaries, collared peccaries, and tapirs were 4.6, 5.1, and 6.2 times lower, respectively. In the case of the white-lipped peccary, the drop in densities mirrored the near absence of the species in hunting registers from 2005 onward. For the collared peccary and the tapir, it was not clear whether the difference in recorded density was because of normal variation in animal distribution or whether the population had been affected by hunting. Caution must therefore be exercised in interpreting the data as a decline in population size.

\section{DISCUSSION}

The Yavari-Mirin region is one of the most remote areas in the Peruvian Amazon. Beyond the current selective extraction of timber, human pressure from hunting and habitat change is low. This area offers the large, intact, and continuous landscape necessary for the long-term viability of species that exist in increasingly fragmented populations, including globally threatened species such as the red uakari monkey (C. calvus), the jaguar $(P$. onca $)$, and the giant river otter $(P$. brasiliensis $)$. The Yavari-Mirin not only represents an important area for biodiversity conservation, but is also an important source area for game animals for the Orosa, Maniti, Tamshiyacu, Tahuayo, 
Table 2. Harvest rates of mammal species by 15 camps during timber operations, shown in terms of individuals and biomass extracted.

\begin{tabular}{|c|c|c|c|c|c|}
\hline Species & $\begin{array}{l}\text { Average Weight } \\
(\mathrm{kg})\end{array}$ & $\begin{array}{l}\text { Individuals Extracted } \\
\text { per Month }\end{array}$ & $\begin{array}{c}\text { Biomass Extracted per } \\
\text { Month }(\mathrm{kg})\end{array}$ & $\begin{array}{c}\text { Individuals Extracted } \\
\text { per Year }\end{array}$ & $\begin{array}{c}\text { Biomass Extracted } \\
\text { per Year }(\mathrm{kg})\end{array}$ \\
\hline \multicolumn{6}{|l|}{ Primates } \\
\hline Alouatta seniculus & 6.5 & 3.5 & 22.7 & 13.9 & 90.6 \\
\hline Ateles chamek & 9.02 & 20.9 & 188.9 & 83.8 & 755.6 \\
\hline Sapajus macrocephalus & 3.5 & 1.2 & 4.2 & 4.8 & 16.8 \\
\hline Cebus yuracus & 2.7 & 2.4 & 6.5 & 9.6 & 25.9 \\
\hline Lagothrix poeppigii & 8.71 & 27.5 & 239.9 & 110.2 & 959.6 \\
\hline Pithecia monachus & 1.8 & 1.2 & 2.2 & 4.8 & 8.6 \\
\hline \multicolumn{6}{|l|}{ Ungulates } \\
\hline Mazama americana & 20 & 50.1 & 1001.3 & 200.3 & 4005.4 \\
\hline Pecari tajacu & 25 & 92.7 & 2317.1 & 370.7 & 9268.5 \\
\hline Tapirus terrestris & 140 & 15.0 & 2096.0 & 59.9 & 8384.0 \\
\hline \multicolumn{6}{|l|}{ Rodents } \\
\hline Cuniculus paca & 8 & 101.9 & 815.5 & 407.7 & 3261.8 \\
\hline Dasyprocta fuliginosa & 5 & 13.4 & 67.2 & 53.7 & 268.7 \\
\hline \multicolumn{6}{|l|}{ Edentates } \\
\hline Dasypus novemcinctus & 6 & 16.2 & 97.0 & 64.7 & 388.1 \\
\hline \multicolumn{6}{|l|}{ Carnivores } \\
\hline Nasua nasua & 5 & 1.3 & 6.4 & 5.1 & 25.7 \\
\hline Total & 241.2 & 347.3 & 6864.8 & 1389.3 & $27,459.3$ \\
\hline
\end{tabular}

Yarapa, Gálvez, and Yaquirana Rivers. The sustainable hunting by local people residing along these rivers depends on the production of wildlife in the Yavari-Mirin basin. There is potential for the effects of timber activities to compromise this source-sink system, resulting in significant economic and sociocultural costs for the rural people. It is estimated that if this were to occur, the Department of Loreto, in the northeastern Peruvian Amazon, would lose $25 \%$ of its current benefits from natural resource use (Bodmer et al. 2003).

In a spatial analysis of the same study area, Mercado (2012) reported a low deforestation rate of $0.10 \%$ and $0.60 \%$ for the periods 2000-2005 and 2005-2010, respectively. These results suggests that selective logging activities conducted by the local indigenous people are not causing a great effect on the forests of the Yavari-Mirin basin, and there are no signs of forest fragmentation that could affect the large mammal populations through wildlife isolation by reducing the available habitat and limiting connectivity. These recent findings show that habitat change is minimal, and any effect of logging activities on large mammal populations is therefore highly likely to be the result of hunting associated with logging operations.

The harvest data we collected concur with those collected during previous studies, which have found that the most frequently hunted species on the timber concessions are the paca, the collared peccary, and the brocket deer, some of the species most suitable for bushmeat hunting (Townsend 2000). Ungulates are the most hunted group, representing $45.4 \%$ of individuals and $78.9 \%$ of biomass. The harvest rate of the lowland tapir is relatively low compared with other areas (Bodmer and Pezo Lozano 2001), but because the species lives at very low and hard-to-survey densities, it is hard to determine what kind of effect these rates will have at the population level. The primary concern regarding timber concessions is that logging often facilitates bushmeat hunting, the effects of which could be far greater than those of habitat disturbance (Robinson et al. 1999). In the Yavari-Mirin basin, harvest rates, including harvests in both the logging concessions and communities, are still lower than in other areas with a higher human presence, such as the Tamshiyacu-Tahuayo Regional Conservation Area (Bodmer and Pezo Lozano 2001).

Care must be taken when interpreting CPUE because it does not always reflect abundance. Selection may occur during hunting, and species living in large groups may be more or less captured in relation to solitary or cryptic species (Maunder et al. 2006, Millner-Gulland and Rowclife 2007). However, the dramatic drop in the CPUE of the white-lipped peccary certainly reflects the population crash in this species, and kill rates of the other ungulates in the subsistence hunting of the community of Esperanza also dropped considerably. For other species, however, CPUE increased. This is consistent with hunters switching to alternative prey items, such as primates and rodents, when the preferred ungulates are not available. The population decline of the white-lipped peccary may be a natural phenomenon; the species has been found to experience large fluctuations in population size roughly every 10 years, and a very low population has been recorded since 2005 (Fang et al. 2008). This may have been exacerbated by a recent large-scale decline in the whitelipped peccary population throughout northern South America (Altrichter et al. 2012), for which nonanthropogenic causes, including disease, could be implicated (Fragoso 2004, RichardHansen et al. 2013). The decline of the white-lipped peccary, rather than hunting in logging concessions, may be the principal driving force behind the switch in prey species. In the case of the tapir, further caution should be exercised in interpreting the 
Table 3. Density and abundance of the most common large mammals of the Yavari-Mirin basin before and after timber operations began (surveys 1 and 2, respectively).

\begin{tabular}{|c|c|c|c|c|c|c|}
\hline \multirow[t]{2}{*}{ Species } & \multicolumn{3}{|c|}{$\begin{array}{c}\text { Survey } 1 \\
\text { (mid- and upper sections of Yavari-Mirin) }\end{array}$} & \multicolumn{3}{|c|}{$\begin{array}{c}\text { Survey } 2 \\
\text { (midsection of Yavari-Mirin) }\end{array}$} \\
\hline & Density & Abundance & $\mathrm{CV}^{\dagger}$ & Density & Abundance & $\mathrm{CV}$ \\
\hline \multicolumn{7}{|l|}{ Primates } \\
\hline Alouatta seniculus & 0.76 & 3.94 & 69.47 & 1.68 & 6.72 & 20.32 \\
\hline Ateles chamek & 1.58 & 7.24 & 43.3 & 4.73 & 14.19 & 36 \\
\hline Cacajao calvus & $\mathrm{NA}^{\ddagger}$ & 6.07 & NA & 9.32 & 37.27 & 39.48 \\
\hline Callicebus cupreus & 11.72 & 23.55 & 18.66 & 2.82 & 11.26 & 26.75 \\
\hline Cebus albifrons & 5.58 & 28.43 & 23.86 & 3.42 & 13.69 & 22.17 \\
\hline Sapajus macrocephalus & 10.2 & 35.78 & 23.2 & 7.41 & 29.62 & 20.74 \\
\hline Lagothrix poeppigii & 24.5 & 28.31 & 16.14 & 35.66 & 142.63 & 12.59 \\
\hline Pithecia monachus & 10.51 & 33.12 & 13.65 & 6.60 & 26.38 & 16.16 \\
\hline Saguinus spp. & 28.52 & 80.1 & 18.26 & 23.59 & 70.75 & 15.43 \\
\hline Saimiri sciureus & 45.9 & 192.96 & 20.15 & 26.97 & 80.90 & 21.5 \\
\hline \multicolumn{7}{|l|}{ Ungulates } \\
\hline Mazama americana & 0.96 & 2.13 & 32.57 & 0.98 & 3.92 & 25.04 \\
\hline Mazama nemorivaga & NA & 0.51 & NA & 0.23 & 0.93 & 27.01 \\
\hline Pecari tajacu & 8.54 & 15.76 & 43.72 & 1.65 & 6.60 & 27.7 \\
\hline Tapirus terrestris & 0.31 & 1.17 & 50.3 & 0.05 & 0.31 & 70.14 \\
\hline Tayassu pecari & 14.59 & 72.94 & 22.44 & 3.16 & 18.98 & 50.5 \\
\hline \multicolumn{7}{|l|}{ Rodents } \\
\hline Dasyprocta fuliginosa & 2.91 & 5.95 & 21.41 & 1.04 & 3.11 & 13.42 \\
\hline Myoprocta spp. & 3.95 & 3.94 & 26.98 & 2.15 & 4.29 & 31.68 \\
\hline Sciurus spp. & 6.7 & 10.44 & 39.06 & 2.51 & 7.53 & 18.99 \\
\hline
\end{tabular}

${ }^{\dagger} \mathrm{CV}$, coefficient of variation.

NA, no analysis.

recorded changes in abundance because behavioral changes, such as increased nocturnal activity, can occur in response to hunting (Eisenberg 1989), which makes detection less likely in surveys, thereby leading to underestimation of population size.

One of the main concerns prior to the logging operations was the risk of population decline of species sensitive to hunting because of low reproductive rates and low population densities, such as the ateline primates and the lowland tapir. The drops of 2.8 and 3.6 times in CPUE for the collared peccary and lowland tapir, respectively, are reflected by differences of 5.1 and 6.2 times in densities, calculated by the distance method, between our baseline calculations from before the logging and the densities calculated for the middle basin after several years of extraction. Although there is no evidence for effects of logging on the densities of other species, the shift in species hunted in Esperanza is something that should be considered carefully.

In the case of the primates, which are considered extremely vulnerable to overhunting because of their slow reproductive rate (Bowler et al. 2014), apparently healthy populations were found in surveys after several years of logging. Population data for Poeppig's woolly monkey, despite being one of the most commonly harvested game species on timber concessions in the Yavari-Mirin basin, did not suggest any negative effects on this species thus far. Several other studies have found stable or increased populations of primates (Ganzhorn 1995, Champan et al. 2000) and ungulates (Davies et al. 2001) in selectively logged forests, as well as carnivores that prey on these species (Rayan and
Mohamad 2009, Tobler et al. 2013). The red uakari monkey is of key conservation concern because it has a patchy distribution along the rivers of the Yavari-Mirin basin and throughout its range (Bowler et al. 2013). The irregular distribution of this monkey means we cannot make inferences based on the densities or abundance calculated from the surveys; however, because hunters do not appear to be harvesting this species during timber operations, it is probable that populations have not been affected. Nevertheless, sharp declines in the populations of this species in other areas (Bowler et al. 2009) where logging operations have occurred urges caution in predicting population trends for this species.

In source areas that provide influx of game to other areas, the effects of logging activity are of particular concern. The Yavari is a large and very remote source area for a large part of eastern Loreto, and it is furthermore surrounded by source areas in Brazil, i.e., Vale do Javari Indigenous Reserve, and Peru, i.e., Matses National Reserve and Zona Reservada Sierra del Divisor. We find that ecological effects of timber activities on wildlife in the YavariMirin basin may not be as severe as initially expected. This may be related to the unusual socioeconomic context of these timber concessions. Perhaps most important in terms of the conservation implications is that in other timber concessions, the sale of bushmeat provides lumbermen with a necessary alternative income until they are able to sell timber, which can take up to a year of unpaid work. However, the sale of bushmeat from timber activities in the Yavari-Mirin basin is restricted by the number of military posts scattered throughout the region because of its 
location along the Peru-Brazil border. Dominating the area are Brazilian military posts, which enforce Brazilian law on the nearby timber concessions and prohibit the sale of bushmeat. The commercialization of bushmeat originating from the YavariMirin basin is therefore limited, restricting hunting on timber concessions to largely subsistence levels. These factors mean that postlogging, the Yavari-Mirin basin can likely continue to act as a source area for large parts of Loreto, representing a large, but hard-to-calculate economic value and also providing subsistence hunting for local people. Add to this the area's undoubted value in carbon stores (Asner et al. 2014) and biodiversity (Pitman et al. 2003), as well as healthy populations of key species of conservation concern such as the giant river otter ( $P$. brasiliensis; Recharte Uscamaita and Bodmer 2010) and the red uakari monkey (Cacajao calvus; Bowler et al. 2013), and it is clear that the the Yavari-Mirin basin retains considerable conservation value despite the ongoing logging operations.

\section{CONCLUSION}

Previous studies have revealed negative effects of selective logging on wildlife populations (Rist et al. 2011). However, conservationists should not dismiss the environmental value of selectively logged forests. The effects of timber operations on wildlife vary from species to species depending on the intensity of logging and the degree of incidental damage caused, the extent to which timber species provide food for wildlife, and whether the timber operations facilitate hunting of particular wildlife species (Johns 1992, Struhsaker 1997, Oates 2004). Our study area is remote and has a high diversity of mammal communities, low human population density, and a consequently low hunting pressure. In remote areas that are important as sources for dispersing game animals, it is possible that these areas can continue to act as source areas after being selectively logged. Although we describe the effect of logging activities by local communities within their territory, these results may be extrapolated with caution to those within timber concessions because local people are usually contracted to extract timber in these areas. We suggest that although there is some evidence that populations of some ungulate species may have declined, these populations likely have the potential to recover (Mayor et al. 2009), and selective logging in timber concessions promoted by the Peruvian government may still be compatible with wildlife conservation, as long as socioeconomic factors in the areas allow. The very low human population in the Yavari region, and the highly seasonal nature of the logging activity, limits periods of elevated hunting. However, the reality may be drastically different elsewhere. For example, in areas with a higher human population, intensive logging, or commercial bushmeat hunting, specific studies will be needed to evaluate the effect of timber activities on wild mammal populations in each area. We add to the increasing evidence that selectively logged forests around the world remain valuable for wildlife. They are important habitats for endangered species and retain a relatively high level of biodiversity (Chapman et al. 2000, Berry et al. 2010, Edwards et al. 2011, Ramage et al. 2013), and they are economically valuable as a source of meat and other nontimber forest products (Rist et al. 2011). As timber concessions cover an increasing area of tropical forests, wildlife conservation will depend on the management of selectively logged forests, together with the preservation of intact primary forests.
Responses to this article can be read online at: http://www.ecologyandsociety.org/issues/responses. php/8023

\section{Acknowledgments:}

We thank all the people from Nueva Esperanza who participated in data collection, showing that communal participation is important in the development of wildlife management. We also thank the Wildlife Conservation Society, the Center for International Forestry Research, the Los Angeles Zoo, the Bushmeat Research Initiative, the Consultative Group for International Agricultural Research, the Forests, Trees and Agroforestry, the U.S. Agency for International Development, the U.K. Agency for International Development, and FundAmazonia for kind assistance during fieldwork and financial support.

\section{LITERATURE CITED}

Altrichter, M., A. Taber, H. Beck, R. Reyna-Hurtado, L. Lizarraga, A. Keuroghlian, and E. W. Sanderson. 2012. Rangewide declines of a key Neotropical ecosystem architect, the Near Threatened white-lipped peccary Tayassu pecari. Oryx 46:87-98. http://dx.doi.org/10.1017/S0030605311000421

Asner, G. P., D. E. Knapp, R. E. Martin, R. Tupayachi, C. B. Anderson, J. Mascaro, F. Sinca, K. D. Chadwick, M. Higgins, W. Farfan, W. Llactayo, and M. R. Silman. 2014. Targeted carbon conservation at national scales with high-resolution monitoring. Proceedings of the National Academy of Sciences of the United States of America 111(47):E5016-E5022. http://dx.doi.org/10.1073/ pnas. 1419550111

Bardales García, J., N. Bendayán Acosta, and L. Verdi Olivares. 2004. Técnicas de preservación y factor de conversión de fauna silvestre en la región Loreto, Perú. Pages 427-433 in R. Bodmer, editor. Resúmenes VI Congreso Internacional Sobre Manejo de Fauna Silvestre en la Amazonía y Latinoamérica. Universidad Nacional de la Amazonía Peruana; Durrell Institute of Conservation and Ecology, Kent University; and Wildlife Conservation Society, Iquitos, Perú. [online] URL: http:// programs.wcs.org/DesktopModules/Bring2mind/DMX/Download. aspx? Command $=$ Core Download\&EntryId $=5067 \&$ PortalId $=8$ 6\&TabId=3469

Barlow, J., W. L. Overal, I. S. Araujo, T. A. Gardner, and C. A. Peres. 2007. The value of primary, secondary and plantation forests for fruit-feeding butterflies in the Brazilian Amazon. Journal of Applied Ecology 44:1001-1012. http://dx.doi. org/10.1111/j.1365-2664.2007.01347.x

Berry, N. J., O. L. Phillips, S. L. Lewis, J. K. Hill, D. P. Edwards, N. B. Tawatao, N. Ahmad, D. Magintan, C. V. Khen, M. Maryati, R. C. Ong, and K. C. Hamer. 2010. The high value of logged tropical forests: lessons from northern Borneo. Biodiversity and Conservation 19(4):985-997. http://dx.doi.org/10.1007/s10531-010-9779$\mathrm{z}$

Bodmer, R. E., T. G. Fang, and L. M. Ibanez. 1988. Ungulate management and conservation in the Peruvian Amazon. Biological Conservation 45:303-310. http://dx.doi.org/10.1016/0006-3207 (88)90061-4 
Bodmer, R. E., and E. Pezo Lozano. 2001. Rural development and sustainable wildlife use in Peru. Conservation Biology 15:1163-1170. http://dx.doi.org/10.1046/j.1523-1739.2001.0150041163. $\underline{x}$

Bodmer, R. E., and P. Puertas. 2003. A brief history of the Yavarí. Pages 172-176 in N. Pitman, C. Vriesendorp, and D. Moskovits, editors. Perú: Yavarí. Rapid Biological Inventories: 11. The Field Museum, Chicago, Illinois, USA.

Bodmer, R. E., P. Puertas, and M. Antunez. 2003. Use and sustainability of wildlife hunting in and around the proposed Yavarí Reserved Zone. Pages 178-185 in N. Pitman, C. Vriesendorp, and D. Moskovits, editors. Perú: Yavarí. Rapid Biological Inventories: 11. The Field Museum, Chicago, Illinois, USA.

Bowler, M., M. Anderson, D. Montes, P. Pérez, and P. Mayor. 2014. Refining reproductive parameters for modelling sustainability and extinction in hunted primate populations in the Amazon. PLoS ONE 9:e93625. http://dx.doi.org/10.1371/ journal.pone.0093625

Bowler, M., J. Noriega Murrieta, M. Recharte, P. Puertas, and R. Bodmer. 2009. Peruvian red uakari monkeys (Cacajao calvus ucayalii) in the Pacaya-Samiria National Reserve - a range extension across a major river barrier. Neotropical Primates 16 (1):34-37. http://dx.doi.org/10.1896/044.016.0108

Bowler, M., J. Valsecchi, H. L. Queiroz, R. Bodmer, and P. Puertas. 2013. Communities and uacaris: conservation initiatives in Brazil and Peru. Pages 359-367 in L. M. Veiga, A. A. Barnett, S. F. Ferrari, and M. A. Norconk, editors. Evolutionary biology and conservation of titis, sakis and uacaris. Cambridge University Press, Cambridge, UK. http://dx.doi.org/10.1017/cbo9781139034210.043

Broadbent, E. N., G. P. Asner, M. Keller, D. E. Knapp, P. J. C. Oliviera, and J. N. Silva. 2008. Forest fragmentation and edge effects from deforestation and selective logging in the Brazilian Amazon. Biological Conservation 141(7):1745-1757. http://dx. doi.org/10.1016/j.biocon.2008.04.024

Buckland, S. T., D. R. Anderson, K. P. Burnham, and J. L. Laake. 1993. Distance sampling: estimating abundance of biological populations. Chapman and Hall, London, UK. http://dx.doi. org/10.1007/978-94-011-1574-2

Chapman, C. A., S. R. Balcomb, T. R. Gillespie, J. P. Skorupa, and T. T. Struhsaker. 2000. Long-term effects of logging on African primate communities: a 28-year comparison from Kibale National Park, Uganda. Conservation Biology 14:207-217. http:// dx.doi.org/10.1046/j.1523-1739.2000.98592.X

Davies, G., M. Heydon, N. Leader-Williams, J. MacKinnon, and H. Newing. 2001. The effects of logging on tropical forest ungulates. Pages 93-124 in R. A. Fimbel, A. Grajal, and J. G. Robinson, editors. The cutting edge-conserving wildlife in logged tropical forest. Columbia University Press, New York, New York, USA.

Edwards, D. P., T. H. Larsen, T. D. S. Docherty, F. A. Ansell, W. W. Hsu, M. A. Derhé, K. C. Hamer, and D. S. Wilcove. 2011. Degraded lands worth protecting: the biological importance of Southeast Asia's repeatedly logged forests. Proceedings of the Royal Society B 278:82-90. http://dx.doi.org/10.1098/rspb.2010.1062
Eisenberg, J. F. 1989. Mammals of the neotropics. University of Chicago Press, Chicago, Illinois, USA.

Fang, T. G., R. E. Bodmer, P. E. Puertas, P. Mayor, P. Pérez-Peña, R. Acero, and D. T. S. Hayman. 2008. Certificación de Pieles Pecaries en la Amazonía Peruana: Una Estrategia para la Conservación y Manejos de Fauna Silvestre en la Amazonía Peruana. Wust Ediciones, Lima, Perú.

Fragoso, J. M. V. 2004. A long-term study of white-lipped peccary (Tayassu pecari) population fluctuation in northern Amazonia. Anthropogenic vs "natural" causes. Pages 286-296 in K. Silvius, R. E. Bodmer, and J. M. V. Fragoso, editors. People in nature. Wildife conservation in South and Central America. Columbia University Press, New York, New York, USA.

Ganzhorn, J. U. 1995. Low-level forest disturbance effects on primary production, leaf chemistry, and lemur populations. Ecology 76:2084-2096. http://dx.doi.org/10.2307/1941683

Gibson, L., T. M. Lee, L. P. Koh, B. W. Brook, T. A. Gardner, J. Barlow, C. A. Peres, C. J. A. Bradshaw, W. F. Laurance, T. E. Lovejoy, and N. S. Sodhi. 2011. Primary forests are irreplaceable for sustaining tropical biodiversity. Nature 478:378-381. http://dx. doi.org/10.1038/nature10425

Johns, A. D. 1992. Vertebrate responses to selective logging: implications for the design of logging systems. Philosophical Transactions of the Royal Society of London B 335:437-442. http:// dx.doi.org/10.1098/rstb.1992.0035

Laurance, W. F., H. L. Vasconcelos, and T. E. Lovejoy. 2000. Forest loss and fragmentation in the Amazon: implications for wildlife conservation. Oryx 34:39-45. http://dx.doi.org/10.1017/ S003060530003088X

Lescuyer, G., S. Assembe Mvondo, J. N. Essoungou, V. Toison, J.-F. Trébuchon, and N. Fauvet. 2012. Logging concessions and local livelihoods in Cameroon: from indifference to alliance? Ecology and Society 17(1):7. http://dx.doi.org/10.5751/ES-04507-170107

Marsden, S. J. 1998. Changes in bird abundance following selective logging on Seram, Indonesia. Conservation Biology 12:605-611.

Maunder, M. N., J. R. Sibert, A. Fonteneau, J. Hampton, P. Kleiber, and S. J. Harley. 2006. Interpreting catch per unit effort data to assess the status of individual stocks and communities. ICES Journal of Marine Science 63(8):1373-1385. http://dx.doi. org/10.1016/j.icesjms.2006.05.008

Mayor, P., R. Bodmer, and M. Lopez-Bejar. 2009. Reproductive performance of the wild white-lipped peccary (Tayassu pecari) female in the Peruvian Amazon. European Journal of Wildlife Research 55:631-634. http://dx.doi.org/10.1007/s10344-009-0312-1

Meijaard, E., D. Sheil, R. Nasi, and S. A. Stanley. 2006. Wildlife conservation in Bornean timber concessions. Ecology and Society 11(1):47. [online] URL: http://www.ecologyandsociety.org/vol11/ iss $1 / \operatorname{art} 471$

Mercado, A. 2012. La deforestación histórica en el paisaje YavaríSamiria: Resultados preliminares. Contribuciones No. 6. Wildlife Conservation Society, Lima, Perú.

Miller, S. D., M. L. Goulden, L. R. Hutyra, M. Keller, S. L. Saleska, S. C. Wofsy, A. M. Silva Figueira, H. R. da Rocha, and 
P. B. de Camargo. 2011. Reduced impact logging minimally alters tropical rainforest carbon and energy exchange. Proceedings of the National Academy of Sciences of the United States of America 108:19431-19435. http://dx.doi.org/10.1073/pnas.1105068108

Millner-Gulland, E. J., and J. M. Rowclife. 2007. Conservation and sustainable use: a handbook of techniques. Oxford University Press, New York, New York, USA. http://dx.doi.org/10.1093/ acprof:oso/9780198530367.001.0001

Ministry of Agriculture (MINAG). 2009. Ley Forestal y de Fauna Silvestre, Ley No. 29376 (11 June 2009). MINAG, Lima, Perú.

Oates, J. F., R. A. Bergl, and J. M. Linder. 2004. Africa's Gulf of Guinea forests: biodiversity patterns and conservation priorities. Advances in Applied Biodiversity Science 6:1-90.

Peres, C. A., and P. M. Dolman. 2000. Density compensation in neotropical primate communities: evidence from 56 hunted and nonhunted Amazonian forests of varying productivity. Oecologia 122:175-189. http://dx.doi.org/10.1007/PL00008845

Pitman, N., C. Vriesendorp, and D. Moskovits, editors. 2003. Perú: Yavarí. Rapid Biological Inventories: 11. The Field Museum, Chicago, Illinois, USA.

Pukazhenthi, B., V. Quse, M. Hoyer, H. van Engeldorp Gastelarrs, O. Sanjur, and L. Brown. 2013. A review of the reproductive biology and breeding management of tapirs. Integrative Zoology 8:18-34. http://dx.doi.org/10.1111/j.1749-4877.2012.12008.x

Putz, F. E., P. A. Zuidema, T. Synnott, M. Peña-Claros, M. A. Pinard, D. Sheil, J. K. Vanclay, P. Sist, S. Gourlet-Fleury, B. Griscom, J. Palmer, and R. Zagt. 2012. Sustaining conservation values in selectively logged tropical forests: the attained and the attainable. Conservation Letters 5:296-303. http://dx.doi. org/10.1111/j.1755-263X.2012.00242.X

Ramage, B. S., D. Sheil, H. M. W. Salim, C. Fletcher, N. Z. Mustafa, J. C. Luruthusamay, R. D. Harrison, E. Butod, A. D. Dzulkiply, A. R. Kassim, and M. D. Potts. 2013. Pseudoreplication in tropical forest and the resulting effects on biodiversity conservation. Conservation Biology 27(2):364-372. http://dx.doi.org/10.1111/cobi.12004

Rayan, D. M., and S. W. Mohamad. 2009. The importance of selectively logged forests for tiger Panthera tigris conservation: a population density estimate in Peninsular Malaysia. Oryx 43:48-51. http://dx.doi.org/10.1017/S0030605308001890

Recharte Uscamaita, M., and R. Bodmer. 2010. Recovery of the endangered giant otter Pteronura brasiliensis on the Yavarí-Mirín and Yavarí Rivers: a success story for CITES. Oryx 44:83-88. http://dx.doi.org/10.1017/S0030605309990196

Richard-Hansen, C., N. Surugue, K. Khazraie, M. Le Noc, and P. Grenand. 2013. Long-term fluctuations of white-lipped peccary populations in French Guiana. Mammalia 78:291-301.

Rist, L., P. Shanley, T. Sunderland, D. Sheil, O. Ndoye, N. Liswanti, and J. Tieguhong. 2011. The impacts of selective logging on non-timber forest products of livelihood importance. Forest Ecology and Management 28:57-69.
Robinson, J. G., K. H. Redford, and E. L. Bennett. 1999. Wildlife harvest in logged tropical forests. Science 284:595-596. http://dx. doi.org/10.1126/science.284.5414.595

Salovaara, K., R. Bodmer, M., Recharte, and C. F. Reyes. 2003. Diversidad y abundancia de mamíferos. Pages 74-82 in N. Pitman, C. Vriesendorp, and D. Moskovits, editors. Perú: Yavarí. Rapid Biological Inventories: 11. The Field Museum, Chicago, Illinois, USA.

Sheil, D., and E. Meijaard. 2010. Purity and prejudice: deluding ourselves about biodiversity conservation. Biotropica 42:566-568. http://dx.doi.org/10.1111/j.1744-7429.2010.00687.x

Slade, E. M., D. J. Mann, and O. T. Lewis. 2011. Biodiversity and ecosystem function of tropical forest dung beetles under contrasting logging regimes. Biological Conservation 144:166-174. http://dx.doi.org/10.1016/j.biocon.2010.08.011

Sodhi, N. S., L. P. Koh, D. M. Prawiradilaga, Darjono, I. Tinulele, D. D. Putra, and T. H. T. Tan. 2005. Land use and conservation value for forest birds in central Sulawesi (Indonesia). Biological Conservation 122:547-558. http://dx.doi.org/10.1016/j.biocon.2004.07.023

Struhsaker, T. T. 1997. Ecology of an African rain forest: logging in Kibale and the conflict between conservation and exploitation. University Press of Florida, Gainesville, Florida, USA.

Thiollay, J. M. 1992. Influence of selective logging on bird species diversity in a Guianan rain forest. Conservation Biology 6:47-63. http://dx.doi.org/10.1046/j.1523-1739.1992.610047.x

Tobler, M. W., S. E. Carrillo-Percastegui, A. Z. Hartley, and G. V. N. Powell. 2013. High jaguar densities and large population sizes in the core habitat of the southwestern Amazon. Biological Conservation 159:375-381. http://dx.doi.org/10.1016/j.biocon.2012.12.012

Townsend, W. R. 2000. The sustainability of subsistence hunting by the Sirionó Indians of Bolivia. Pages 267-281 in J. G. Robinson and E. L. Bennet, editors. Hunting for sustainability in tropical forests. Columbia University Press, New York, New York, USA.

Uhl, C., A. Verissimo, M. M. Mattos, Z. Brandino, and I. C. G. Vieira. 1991. Social, economic, and ecological consequences of selective logging in an Amazonian frontier: the case of Tailândia. Forest Ecology and Management 46:243-273. http://dx.doi. org/10.1016/0378-1127(91)90235-N

Verissimo, A., P. Barreto, M. Mattos, R. Tarifa, and C. Uhl. 1992. Logging impacts and prospects for sustainable forest management in an old Amazonian frontier: the case of Paragominas. Forest Ecology and Management 55:169-199. http:// dx.doi.org/10.1016/0378-1127(92)90099-U

Watson, F. 1996. A view from the forest floor: the impact of logging on indigenous peoples in Brazil. Botanical Journal of the Linnean Society 122:75-82. http://dx.doi.org/10.1111/j.1095-8339.1996. $\underline{\text { tb02064.x }}$

Xingli G., G. R. Clements, S. A. Aziz, K. Y. Chong, and J. Miettinen. 2011. Rethinking the 'back to wilderness' concept for Sundaland's forests. Biological Conservation 144:3149-3152. http://dx.doi.org/10.1016/j.biocon.2011.10.001 